\title{
Perlindungan Hukum Bagi Pemegang Hak Desain Industri Eco Bottle Terhadap Tindakan Pemalsuan (Studi Perbandingan Dengan Amerika Serikat)
}

\author{
Muyassar Nugroho \\ Magister Ilmu Hukum Kekhususan Hukum Ekonomi Universitas Indonesia
}

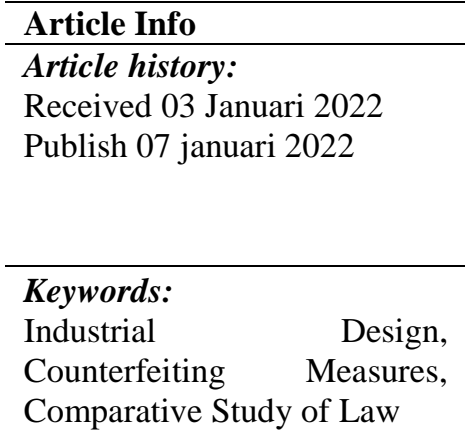

\section{Info Artikel}

Article history:

Diterima 03 Januari 2022

Publis 07 januari 2022

\begin{abstract}
The development of the bottle industry in Indonesia today raises new problems where bottle design similarity between several brands is a new problem that arises. Holders of bottle industry design rights that should be heavily protected are not yet fully strong legal protections and no regulation that discusses in detail about imitation/design forgery. This writing uses a comparative method that the author compares with the United States that has protected the holder of Industrial Design Rights since 1989 and proved successful in protecting the holder of Industrial Design Rights, therefore this comparison is important so that regulations on Industrial Design Rights in Indonesia can be useful to industrial design rights holders.
\end{abstract}

Corresponding Author:

Muyassar Nugroho

Magister Ilmu Hukum Kekhususan Hukum Ekonomi Universitas Indonesia

Email: muyassarnugish@gmail.com

\section{PENDAHULUAN}

\section{Latar belakang}

Keikutsertaan Indonesia dalam meratifikasi Agreement Establishing The World Trade Organization (selanjutnya disebut WTO) yang mencakup pula Agreement on Trade Related Aspect of Intellectual Property Right (selanjutnya disebut Perjanjian TRIPs) sebagaimana telah diratifikasi dengan Undang-Undang Nomor 7 tahun 1994 Tentang Pengesahan Agreement Establishing The World Trade Organization. Ratifikasi atas persetujuan-persetujuan tersebut mendukung ratifikasi Paris Convention for the Protection of Industrial Property Rights (Konvensi Paris) dengan Keputusan Presiden Nomor 15 Tahun 1997, mengakibatkan Indonesia harus membentuk dan menyempurnakan hukum nasionalnya. Indonesia harus memandang sisi perdagangan internasional yang menimbulkan adanya persaingan tersebut sebagai suatu hal yang mempunyai arti sangat penting. Pembangunan di bidang ekonomi yang akan semakin menitikberatkan pada sektor industri terutama yang berorientasi ekspor memerlukan pengamanan bagi pemasarannya. 
Sebagai bentuk konsekuensi dari ratifikasi Undang-Undang Nomor 7 tahun 1994 Tentang Pengesahan Agreement Establishing The World Trade Organization, Indonesia menyempurnakan peraturan perundang-undangan di bidang Hak Kekayaan Intelektual (selanjutnya disebut HKI). Dimulai dengan di ubahnya Undang-Undang Nomor 7 Tahun 1987 Tentang Hak Cipta dengan Undang - Undang Nomor 12 tahun 1997, yang kemudian di ubah Kembali dengan Undang-Undang Nomor 19 Tahun 2002 Tentang Hak Cipta. Begitu pula dengan Undang-Undang Nomor 6 Tahun 1989 Tentang Merek yang diubah dengan UndangUndang Nomor 13 Tahun 1997 yang kemudian diubah kembali dengan Undang Undang Nomor 15 Tahun 2001. Serta Undang-Undang Nomor 19 Tahun 1992 Tentang Paten yang diubah dengan Undang-Undang Nomor 14 Tahun 1997 yang di ubah kembali dengan Undang-Undang Nomor 14 Tahun 2001. Indonesia juga telah mengesahkan Undang-Undang Nomor 30 Tahun 2000 Tentang Rahasia Dagang, Undang-Undang Nomor 31 Tahun 2000 Tentang Desain Industri (selanjutnya disebut Undang-Undang Desain Industri), dan Undang-Undang Nomor 32 Tentang Tata letak Sirkuit Terpadu.

Sebagai negara berkembang, Indonesia harus memandang sisi kompetitif perdagangan internasional sebagai sesuatu yang sangat penting. Pembangunan sektor ekonomi akan semakin fokus pada sektor industri yang berorientasi ekspor, sehingga perlu diberikan jaminan keamanan untuk pemasarannya. Tanpa ini, perlindungan produk industri, termasuk produk yang dihasilkan oleh kecerdasan manusia, telah menjadi isu yang tidak dapat dipisahkan dari kerangka perdagangan bebas. Salah satu produk yang dihasilkan oleh kecerdasan manusia adalah desain industri. Dalam perkembangan desain industri, ia memegang peranan penting dalam keberhasilan industri dan perdagangan suatu negara. Desain industri merupakan sarana untuk memperoleh nilai tambah yang tinggi dalam suatu industri. Oleh karena itu, negara industri maju seperti Amerika Serikat, Inggris, dan Jepang telah memberikan perhatian khusus pada desain Industri.

Pasal 1 Ayat 1 Undang-Undang No. 31 Tahun 2000 tentang Desain Industri mendefinisikan desain Industri Sebagai ciptaan garis atau warna atau bentuk, konfigurasi atau komposisi garis dan warna, dapat berupa tiga dimensi atau dua dimensi, dapat memberikan rasa keindahan, dan dapat diwujudkan dalam tiga dimensi atau dua dimensi. bentuk, pola ukuran dapat digunakan untuk produksi Komoditas, barang industri atau kerajinan tangan. Hasil dari ide yang dituangkan manusia menjadi sebuah karya merupakan kekayaan intelektual yang seharusnya dilindungi oleh hukum selama berguna untuk masyarakat luas dan tidak melanggar norma dan aturan yang berlaku.

Dari sini dapat dikatakan bahwa pada prinsipnya yang dilindungi oleh desain industri adalah tampilan produk, atau hanya tampilan visualnya saja. Sementara, aspek teknis, teknologi dan fungsional dari suatu produk dilindungi oleh hukum paten.

Jika dibandingkan dengan ketentuan Desain Industri dalam Part II Section 4 TRIPs Agreement khususnya dalam pasal 25 dan pasal 26, disimpulkan bahwa pada intinya ketentuan dalam Perjanjian TRIPs tentang Desain Industri mengatur bahwa:

a. Desain industri yang dapat dilindungi adalah desain industri yang baru atau orisinal;

b. Hak desain industri yang mencakup membuat, menjual, atau mengimpor dan termasuk mencegah pihak lain yang melakukan hal tanpa izin pemegang hak, dan

c. Jangka waktu perlindungan minimal 10 tahun.

Undang-Undang Desain Industri yang Indonesia miliki pada dasarnya hanya menelan secara utuh ketentuan yang terkandung dalam pasal Perjanjian TRIPs tentang Desain Industri, hal ini terlihat dari ketentuan pasal 2 Undang-Undang Desain Industri yang mengemukaan desain industri yang dapat memperoleh perlindungan meliputi:

a. Hak desain industri diberikan untuk desain industri yang baru

b. Desain industri dianggap baru apabila pada tanggal penerimaan, desain industri tersebut tidak sama dengan pengungkapan yang telah ada sebelumnya

c. Pengungkapan sebelumnya, sebagaimana dimaksud dalam ayat (2) adalah pengungkapan desain industri yang sebelum (i) tanggal penerimaan; (ii) tanggal prioritas apabila 
permohonan diajukan dengan hak prioritas; dan (iii) telah diumumkan atau digunakan di Indonesia atau diluar Indonesia.

Tujuan pengungkapan dalam UU Desain Industri adalah pengungkapan melalui media cetak atau elektronik, termasuk keikutsertaan dalam pameran. Berdasarkan pengertian Pasal 2 dapat disimpulkan bahwa apabila pada tanggal diterimanya Desain yang didaftarkan, Desain Industri tersebut berbeda dengan pengungkapan yang telah ada sebelumnya, maka Desain Industri tersebut dianggap sebagai penampakan baru. Oleh karena itu, pengungkapan desainer sebelumnya akan menghilangkan unsur kebaruan. Selain itu, "UU Desain Industri" tidak mengadopsi metode orisinal, tetapi menekankan apakah desain industri itu baru atau tidak.

Akibatnya timbul masalah mendasar dalam perlindungan desain industri di Indonesia, karena Undang-Undang Desain Industri atau peraturan perundang-undangan lainnya yang berlaku tidak memberikan definisi dan pemahaman yang jelas tentang bagaimana prinsip kebaruan digunakan, sehingga menjadi desain industri Indikatornya bisa dikatakan baru, karena dari pengertian Pasal 2 UU Desain Industri, hanya desain industri yang didaftarkan sejak tanggal penerimaan pendaftaran dan pengungkapan keberadaan sebelumnya. . Klausul ini sama sekali tidak memberikan kepastian yang jelas tentang prinsip kebaruan desain.

Ketidak tegasan Undang-Undang Desain Industri dalam mengatur metode pendekatan untuk menilai unsur kebaruan telah menimbulkan ketidak pastian hukum. Tidak ada satupun ketentuan dalam Undang-Undang Nomor 31 Tahun 2000 tentang Desain Industri yang mencantumkan penjelasan mengenai prinsip dari kebaruan (Novelty) dari sebuah desain indutri yang terdaftar, sehingga dalam prakteknya penafsiran terhadap ketentuan pasal tersebut diserahkan kepada hakim dalam proses pengadilan jika terjadi sengketa.

Lemahnya aturan terhadap pemalsuan di Indonesia, menyebabkan banyak produk-produk yang memiliki kemiripan desain industri sangat tinggi beredar di masyarakat, penulis mengambil contoh dari brand yang viral yaitu botol kemasan eco bottle dan Biolife. Eco bottle lebih dahulu hadir dengan desain empat lekukan mencekung ke dalam di bagian tengah botol yang secara visual menyerupai angka 8. Lalu lahirlah Botol biolife yang mempunyai kemiripan desain siluet konfigurasi yang sangat mirip dengan milik eco bottle.

Penulis mengambil kasus tentang pelanggaran desain industri antara desain industri Produk kemasan konsumsi Eco Bottle milik Tupperware dengan Produk kemasan konsumsi Biolife, dimana keduanya memiliki desain industri yang hampir sama pada konfigurasinya. Sehingga DART INDUSTRIES INC. yang merupakan pemilik dari perusahaan Tupperware mengajukan gugatan di Pengadilan Niaga pada Pengadilan Negeri Semarang kepada para tergugat yang salah satunya merupakan produsen dari produk kemasan konsumsi Biolife dimana produk kemasan konsumsi tersebut memiliki desain industri yang konfigurasinya hampir sama dengan produk kemasan konsumsi Eco Bottle milik Tupperware yang telah di daftarkan di Direktorat Jendral Kekayaan Intelektual. Gugatan yang diajukan oleh pihak Tupperware di Pengadilan Niaga pada Pengadilan Negeri Semarang tersebut sudah memperoleh putusan yang mana gugatan tersebut tidak diterima oleh Majelis Hakim Pengadilan Niaga pada Pengadilan Negeri Semarang, kemudian pihak Tupperware mengajukan permohonan kasasi dan permohonan tersebut diterima oleh Majelis Hakim Mahkamah Agung. Hal ini menunjukkan bahwa pengadilan di Indonesia masih sangat kurang dalam memberikan perlindungan desain industri.

Dalam melakukan penelitian, Penulis memilih metode perbandingan dan memilih negara Amerika Serikat sebagai negara pembanding. Alasan penulis memilih AS karena desain industri telah dikenal disana sejak tahun 1989 dan banyak kasus yang melindungi desain industri di AS. Contohnya di AS sudah diatur 5 unsur untuk mendapatkan perlindungan yaitu unsur kebaruan, ketidak samaan, keaslian, elemen hias, dan diproduksi.

\section{Rumusan Masalah}

1. Bagaimanakah bentuk perlindungan hukum bagi pemegang hak desain industri eco bottle terhadap tindakan pemalsuan berdasarkan Undang-undang 31 tahun 2000 tentang desain industri dan keterkaitannya dengan TRIPs Agreement? 
2. Bagaimanakah pemerintah Indonesia dapat meningkatkan perlindungan hukum bagi pemegang hak desain industri botol berdasarkan studi perbandingan dengan negara Amerika Serikat?

\section{Tujuan penelitian}

Adapun tujuan penelitian yang hendak dicapai oleh penulis dalam penelitian ini adalah:

1. Untuk mengetahui bentuk perlindungan hukum bagi pemegang hak desain industri eco bottle terhadap tindakan pemalsuan berdasarkan Undang-undang 31 tahun 2000 tentang desain industri dan dikaitkan dengan TRIPs Agreement.

2. Untuk mengetahui pemerintah Indonesia dapat meningkatkan perlindungan hukum bagi pemegang hak desain industri berdasarkan studi perbandingan dengan negara Amerika Serikat.

\section{METODE PENELITIAN}

Penelitian ini merupakan penelitian yuridis normatif yakni penelitian yang difokuskan untuk mengkaji penerapan kaidah-kaidah atau norma-norma dalam hukum positif. Pendekatan yuridis yaitu metode mengkaji masalah berdasarkan peraturan yang berlaku di Indonesia, sedangkan metode normatif adalah metode pengecekan masalah dengan cara memeriksa apakah sesuatu baik (benar atau tidak) sesuai ketentuan yang berlaku. Dalam penelitian ini penulis menggunakan metode pendekatan perbandingan (comparative approach) yaitu penulis membandingkan peraturan suatu negara dengan negara lainnya, melihat isi persamaan dan perbedaan hukum serta analisa untuk mendapatkan jawaban dari suatu permasalahan yang ada. Sumber data yang digunakan dalam penelitian ilmiah ini berupa data sekunder dan data primer. Data sekunder yaitu hukum primer, sekunder dan tersier yang dijadikan data utama. Didukung oleh data primer sebagai penunjang data sekunder. Teknik pengumpulan data yang dilakukan penulis adalah penelitian kepustakaan, yaitu melalui eksplorasi dan analisis bahan pustaka yang berkaitan dengan hak desain industri. Teknik Analisa yang digunakan penulis adalah teknik analisa data kualitatif yaitu pengolahan data yang telah dikumpulkan dari data primer untuk menjawab rumusan masalah.

\section{PEMBAHASAN}

Perlindungan Hukum Bagi Pemegang Hak Desain Industri Eco Bottle Terhadap Tindakan Pemalsuan Berdasarkan Undang-Undang 31 Tahun 2000 Tentang Desain Industri Dan Keterkaitannya Dengan Trips Agreement

Berdasarkan ketentuan Pasal 25 ayat (1) Persetujuan TRIPs dapat disimpulkan bahwa TRIPs mensyaratkan untuk dapat memperoleh perlindungan, suatu desain industri harus baru atau asli serta merupakan hasil karya secara bebas (independently).

Persyaratan untuk dilindunginya suatu desain industri, yaitu harus baru atau asli, merupakan suatu persyaratan yang mutlak harus dipenuhi oleh setiap Negara anggota. Untuk menentukan apakah suatu desain tersebut baru atau asli, suatu Negara diberi kebebasan untuk menentukan baru atau aslinya suatu desain dan dapat menunjuk pada ketentuan yang menyatakan bahwa Negara anggota dapat menetapkan tidak baru atau asli suatu desain jika desain industri tersebut tidak memiliki perbedaan berarti dengan desain yang telah dikenal atau kombinasi dari ciri-ciri desain yang telah terkenal. Jeremy Phillips dan Alison Firth berpendapat bahwa desain mencakup segala aspek tentang bentuk atau konfigurasi susunan baik internal maupun eksternal baik yang merupakan bagian maupun keseluruhan dari sebuah benda. Dekorasi permukaan dikesampingkan dan suatu desain harus spesifik.

Pada prinsipnya hak desain industri diberikan kepada desain baru. Baru artinya desain tersebut belum pernah ada dan berbeda dengan desain yang sudah ada sebelumnya pada saat desain tersebut didaftarkan. Permintaan diajukan dengan hak prioritas.

Mengenai kriteria kebaruan ini, TRIPs di dalam Pasal 25 sebenarnya memberikan keleluasaan bagi negara anggota untuk memilih sendiri apakah akan menerapkan kriteria "baru" (new) ataukah "orisinal" (originality). Orisinalitas mempunyai arti bahwa sesuatu yang 
langsung berasal dari sumber asal orang yang mebuat atau yang menciptakan astau sesuatu yang langsung dikemukakan oleh orang yang dapat membuktikanya.

Atas alternatif tersebut, Indonesia lebih memilih kriteria "baru" sebagai dasar bagi pengakuan sebuah desain. Dasar pertimbangan pemilihan kriteria tersebut adalah karena penerapan kriteria orisinalitas memerlukan pemeriksaan yang lebih rumit, sedangkan pada saat dibentuknya UU Desain Industri ini, sumber daya untuk pemeriksaan persyaratan orisinalitas masih sangat terbatas.

Undang-Undang Nomor 31 Tahun 2000 secara terperinci memberikan pengaturan mengenai desain industri. Adapun pengaturan desain industri secara khusus hanya diberikan oleh Persetujuan TRIPs dalam Bagian 4 pada Pasal 25 yang mengatur tentang persyaratan untuk perlindungan dan Pasal 26 yang mengatur tentang perlindungan. Hal ini karena Persetujuan TRIPs mengatur ketentuan tentang HAKI secara keseluruhan, bukan hanya mengenai desain industri. Lebih jauh, pengaturan mengenai desain industri secara lebih lengkap juga dapat ditemukan dalam berbagai konvensi internasional yang mengatur tentang desain industri, seperti Konvensi Paris, Konvensi Berne, Persetujuan Hague 1925, dan Persetujuan Locarno 1972.

Persetujuan TRIPs memberikan kebebasan kepada setiap Negara anggota untuk menentukan cara-cara yang dianggap sesuai untuk menerapkan ketentuan-ketentuan yang tercantum dalam Persetujuan TRIPs ke dalam sistem hukum dan praktik hukum mereka. Hal ini sesuai dengan prinsip free to determine yang terdapat dalam Persetujuan TRIPs. Setiap Negara anggota wajib menyesuaikan peraturan perundang-undangannya dengan berbagai konvensi internasional di bidang HAKI. Ini merupakan prinsip Intelectual Property Convention.

Bahwa terkait dengan perlindungan hukum, maka mengutip dari penyataan M. Philipus Hadjon, perlindungan hukum ialah perlindungan akan harkat dan martabat, serta pengakuan terhadap hak-hak asasi manusia yang dimiliki oleh subyek hukum berdasarkan ketentuan hukum dan kesewenangan. Definisi ini juga berlaku pada perlindungan hukum pada pemegang desain industri seyogiyanya harus dilindungi terkait pengakuan hak atas ciptaannya. Lebih lanjut, dalam memberikan perlindungan hukum terdapat 2 mekanisme, yakni perlindungan hukum yang bersifat preventif dan represif.

a. Sarana Perlindungan Hukum Preventif

Sarana preventif, subyek hukum memiliki kesempatan untuk mengajukan keberatan atau pendapat sebelum pemerintah mengambil keputusan untuk mencegah perselisihan. Perlindungan hukum preventif akan berdampak pada tindakan pemerintah yang berbasis kebebasan bergerak, karena Perlindungan hukum preventif mendorong pemerintah lebih berhati-hati dalam pengambilan keputusan. Pada konteks ini perlindungan hukum preventif merupakan perlindungan hukum yang diberikan oleh pemerintah untuk mencegah adanya tindakan imitasi atas suatu hak desain industri.

Sejauh ini, perlindungan preventif yang dimiliki Indonesia telah diatur dalam Pasal 2 UU Desain Industri, yaitu:

(1) Hak Desain Industri diberikan untuk Desain Industri baru.

(2) Jika pada tanggal penerimaan desain industri berbeda dengan yang terungkap, maka desain industri tersebut tergolong baru.

(3) Pengungkapan terlebih dahulu sebagaimana dimaksud pada ayat (2) merupakan pengungkapan terlebih dahulu Desain Industri yang sebelum:

a. tanggal penerimaan; atau

b. tanggal prioritas;

c. telah diumumkan atau digunakan di Indonesia atau di luar Indonesia.

Selanjutnya Pasal 6 juga memberikan perlindungan preventif pada hak pemegang desain industri, yang menyatakan bahwa:

(1) Pendesain atau orang yang memperoleh hak-hak tersebut di atas dari Pendesain yang berhak atas hak Desain Industri. 
(2) Jika Pendesain terdiri dari beberapa orang, kecuali disepakati lain, Hak Desain Industri menjadi milik kolektif, kecuali jika diperjanjikan lain.

Terakhir, Pasal 9 melengkapi perlindungan preventif dengan cara memberikan hak ekskusif untuk pemegang hak desain industri yaitu:

(1) Pemegang Hak Desain Industri memiliki hak eksklusif untuk menggunakan Hak Desain Industri dan melarang pihak lain untuk membuat, menggunakan, menjual, mengimpor, mengekspor, dan / atau mendistribusikan Desain Industri tersebut tanpa persetujuannya Hak atas barang.

Dengan adanya aturan diatas selaku sarana perlindungan preventif diharapkan memberikan perlindungan pemegang hak industri dari pihak ketiga yang ingin mengambil keuntungan dengan cara melakukan imitasi. Namun bila tindakan imitasi tetap terjadi maka alternatif yang dapat diambil adalah sarana perlindungan hukum represif.

b. Sarana Perlindunagan Hukum Represif

Sarana Represif dimaksudkan untuk menyelesaikan sengketa melalui lingkup pengadilan umum dan pengadilan administrasi. Prinsip perlindungan hukum dari tindakan pemerintah mengacu pada konsep pengakuan dan perlindungan hak asasi manusia yang bertujuan untuk membatasi dan memperjelas kewajiban masyarakat dan pemerintah. Ini terkait dengan pengakuan dan perlindungan hak asasi manusia.

Dalam UU desain Industri sarana perlindungan represif jauh lebih lengkap dibanding

Sarana preventif nya. Tertera pada pasal 37 yang menjelaskan mengenai pembatalan pendaftaran yang berbunyi:

(1) Berdasarkan permintaan tertulis dari pemegang Hak Desain Industri, Administrasi Negara dapat membatalkan pendaftaran Desain Industri tersebut.

(2) Dalam hal penerima Izin Desain Industri yang terdaftar dalam Daftar Umum Desain Industri tidak memberikan persetujuan tertulis, pembatalan hak Desain Industri sebagaimana dimaksud pada ayat (1) tidak dilanjutkan. Aplikasi untuk pembatalan pendaftaran ini. yaitu

Selanjutnya pada pasal 39 juga membahas mengenai sarana perlindungan represif tata cara gugatan yang berbunyi:

(1) Ketua Pengadilan Niaga mengajukan gugatan untuk mencabut pendaftaran Desain Industri di domisili atau yurisdiksi tergugat.

(2) Jika tergugat bertempat tinggal di luar wilayah Indonesia, maka gugatan diajukan kepada Ketua Pengadilan Niaga Pusat Jakarta.

(3) Panitera mendaftar untuk membatalkan gugatan pada hari gugatan diajukan dan memberikan tanda terima tertulis kepada penggugat yang ditandatangani oleh anggota staf pada tanggal yang sama dengan tanggal pendaftaran gugatan........"

Dan didalam pasal 54 juga dibahas mengenai sarana perlindungan secara represif yaitu

ketentuan pidana juga diatur dalam pasal 54 yang berbunyi:

(1) Barangsiapa dengan sengaja dan tanpa hak melakukan perbuatan sebagaimana dimaksud dalam Pasal 9 dipidana dengan pidana penjara paling lama empat (empat) tahun dan / atau denda paling banyak Rp 300.000.000,00.

(2) Barangsiapa dengan sengaja melanggar Pasal 8, Pasal 23 atau Pasal 32 dipidana dengan pidana penjara paling singkat satu tahun dan / atau denda paling banyak Rp45.000.000,00.

(3) Tindak pidana sebagaimana dimaksud dalam ayat (1) dan ayat (2) merupakan delik aduan. 
Walaupun sebenarnya Indonesia telah memiliki kedua sarana yang lengkap untuk melakukan perlindungan terhadap pemegang hak desain industri namun sayang Indonesia masih belum mengatur secara rinci tentang produk imitasi/pemalsuan dalam desain industri. Pengaturan suatu produk hanya tertera dalam pasal 4 UU Desain Industri yang Menyatakan bahwa jika Desain Industri melanggar peraturan perundang-undangan, ketertiban umum, agama, atau kesusilaan, hak Desain Industri tidak dapat diberikan. Tidak ada pengaturan lebih lanjut mengenai Batasan-batasan suatu desain agar tidak menimbulkan imitasi/pemalsuan produk.

c. Putusan Mahkamah Agung Nomor: 594K/Pdt.Sus-HKI/2017 yang membatalkan putusan Pengadilan Niaga Semarang Nomor 02/Pdt.Sus HAKI /2016/PN.Niaga.Smg terhadap sengketa desain industri eco bottle dan biolife

Objek analisa dalam hal ini adalah Putusan Kasasi Mahkamah Agung Nomor: 594 K/Pdt.Sus-HKI/2017. Tanggal 4 Agustus 2017. Pemeriksaan Kasasi dalam hal ini berasal dari Putusan Pengadilan Niaga pada Pengadilan Negeri Semarang Nomor: 02/Pdt.SusHAKI/2016/PN tanggal 27 Desember 2016.

Adapun yang merupakan pihak-pihak dalam pemeriksaan di tingkat kasasi ini adalah :

1. Para Pemohon Kasasi yaitu: DART INDUSTRIES, Inc., adalah perusahaan yang berlokasi di Florida, Amerika Serikat. Perusahaan ini sepenuhnya dimiliki oleh Tupperware Brands Corporation, yang bergerak di bidang pembuatan bahan kemasan menggunakan resin plastik yang ditemukan oleh pendiri perusahaan Earl Silas Tupper. Dalam artikel ini, singkatan DART, Inc. dapat digunakan.

2. Pihak Termohon Kasasi, Yakni enam orang pengusaha yang bergerak dalam bidang penjualan barang-barang termasuk di dalamnya adalah kemasan-kemasan plastik untuk wadah penyimpanan makanan. Mereka terdiri dari: (1) MARIANA, Semarang; (2) RETNO PALUPI WAHYUNINGTYAS, Semarang; (3) LILY/LIE FANG, Solo; (4) YUNI INDRAWATI, Yogjakarta (5) RIZA YULINA AMRY, Yogjakarta; dan (6) KEZIA DINA SONGTIANA, Yogjakarta. Dalam Tulisan ini selanjutnya dapat disingkat MARIANA dKK.

Gugatan Penggugat (DART Inc.) didasarkan pada perbuatan melawan hukum Tergugat (MARIANA dkk.) sehingga mengakibatkan kerugian. Hak DART Inc. dalam hal ini adalah Hak Desain Industri atas konfigurasi dari Botol sebagaimana telah terdaftar dalam Daftar Umum desain industri Indonesia nomor: ID 0024 152-D atas nama DART INDUSTRY, Inc. Desain Industri Botol tersebut kemudian diberi nama dan dikenalkan kepada masyarakat dengan nama "Eco Bottle". Dalam rangka menjalankan usahanya tersebut, DART Inc. menemukan adanya penjualan botol bukan berasal dari DART Inc., yang beredar dalam perdagangan, yang bentuk konfigurasinya memiliki persamaan yang signifikan dengan botol DART Inc. sebagaimana telah terdaftar pada Daftar Umum DI Indonesia dengan nomor: ID 0024 152-D. Botol yang disangka melanggar haknya tersebut biasa dikenal atau menggunakan merek "Biolife", yang kemudian diketahui para penjualnya adalah MARIANA dkk.

Dart Inc. mendasarkan haknya pada Pasal 9 ayat (1) Undang-undang Nomor 31 Tahun

2000 tentang Desain Industri, yang mengatur bahwa: "Pemegang hak desain Industri memiliki hak eksklusif untuk melaksanakan Hak Desain Industri yang dimilikinya dan untuk melarang orang lain yang tanpa persetujuannya membuat, memakai, menjual, mengimpor, mengekspor, dan/atau mengedarkan barang yang diberi Hak Desain industri”.

Dalam Bagian Penjelasan dari ketentuan pasal 9 tersebut, dinyatakan bahwa: "Hak Eksklusif adalah hak yang diberikan kepada pemegang hak desain industri untuk dalam jangka waktu tertentu melaksanakan sendiri atau memberikan izin kepada pihak lain. Dengan demikian, pihak lain dilarang melaksanakan Hak Desain Industri tersebut tanpa 
persetujuan pemegangnya. Pemberian hak kepada pihak lain dapat dilakukan melalui pewarisan, hibah, wasiat, perjanjian atau sebab-sebab lain"

Selanjutnya, Dart Inc. mendasarkan hak gugatnya pada Pasal 46 ayat (1) UndangUndang Nomor 31 Tahun 2000 tentang Desain Industri yang mengatur bahwa:

(1) Pemegang Hak Desain Industri atau Penerima Lisensi dapat menggugat sipapun yang dengan sengaja dan tanpa hak melakukan perbuatan sebagaimana dimaksud dalam Pasal 9, berupa:

(a) Gugatan ganti rugi, dam/atau

(b) Penghentian semua perbuatan sebagaimana dimaksud dalam Pasal 9.

Namun pada akhirnya Putusan Pengadilan Niaga Pada Pengadilan Negeri semarang Nomor 02/Pdt.Sus-HAKI/2016/PN Niaga Smg tanggal 27 Desember 2016, menyatakan gugatan DART Inc. tidak dapat diterima. Kemudian DART Inc. melanjutkan ke tingkat kasasi karena merasa tidak puas atas keputusan sebelumnya.

Kemudian pertimbangan dan putusan majelis hakim kasasi berbeda pendapat dan menyatakan bahwa hakim PN salah menerapkan Hukum. Hakim kasasi berpendapat bahwa:

1. Ketentuan Pasal 9 ayat (1) juncto Pasal 46 ayat (1) Undang-Undang nomor 31 tahun 2000 tentang Desain Industri "siapapun tidak terbatas pada produsen yang menggunakan desain industri tanpa hak adalah perbuatan melawan hukum".

2. Bahwa MARIANA dkk. adalah pihak yang menjual atau memasarkan produk sehingga

meskipun bukan produsen adalah termasuk pihak yang terkena ketentuan UndangUndang Desain Industri.

Berdasarkan prinsip tersebut di atas kemudian majelis hakim kasasi memutuskan untuk menerima permohonan kasasi dan membatalkan Putusan PN Semarang. Kemudian Majelis Kasasi melakukan pemeriksaan pokok perkara dan memutuskan menerima Petitum 2, Petitum 3, Petitum 4, petitum 5, petitum 6, petitum 8 dan sebagian petitum 7 (yang mengharuskan MARIANA dkk. untuk membayar ganti kerugian yang materiil sebesar Rp. 125.000.000 (seratus dua puluh lima juta rupiah).

Isu pokok dalam kasus ini adalah tidak diterimanya Gugatan DART Inc. oleh Pengadilan Niaga Pada Pengadilan Negeri Semarang berdasarkan pendapat bahwa Tergugat (MARIANA dkk.) hanyalah sekedar pihak yang menjual atau memasarkan barang, bukan produsen dari barang yang terdapat hak Desain Industri di dalamnya (karena itu tidak dapat dikenakan pasal 9 ayat 1 juncto Pasal 46 ayat (1) UU Desain Industri. No. 31 tahun 2000. Pendapat PN tersebut kemudian dikoreksi oleh MA di tingkat kasasi dengan menyatakan bahwa siapapun yang menggunakan Hak Desain Industri tanpa hak adalah perbuatan melawan hukum.

Pendapat PN Semarang di atas merupakan penafsiran yang dapat mempersempit pihak-pihak yang dapat dikenakan melanggar hak DI orang lain hanya bagi mereka yang berstatus produsen barang yang mengandung DI, tidak termasuk pihak yang sekedar menjual atau mengedarkan barang tersebut. Putusan MA justru memberikan perluasan pada penafsiran Pasal 9 ayat (1) UU desain Industri tersebut dengan menyatakan: “... siapapun tidak terbatas pada produsen yang menggunakan Desain Industri tanpa hak adalah perbuatan melawan hukum”. Prinsip ini lebih luas dari yang disebutkan dalam pasal 9 ayat (1) itu sendiri yakni: “...membuat, memakai, menjual, mengimpor, mengekspor, dan/atau mengedarkan barang yang diberi Hak Desain industri”.

Amanat TRIPS Agreement yang seharusnya Indonesia terapkan yaitu berdasarkan pasal 25 ayat 1 dan pasal 26 ayat 1 TRIPS Agreement. Pasal 25 ayat 1 mengamanatkan bahwa Anggota harus memberikan perlindungan desain industri yang baru atau asli dibuat sendiri. Anggota dapat menetapkan bahwa desain tidak baru atau asli jika tidak berbeda secara signifikan dari desain atau kombinasi fitur desain yang diketahui. Anggota dapat menetapkan bahwa perlindungan tersebut tidak boleh mencakup desain yang pada 
dasarnya ditentukan oleh pertimbangan teknis atau fungsional. Ini jelas bahwa produk imitasi tidak boleh dilindungi yang dimana pemegang hak desain harus mendapatkan haknya sebagai pemiliki desain. Pasal 26 ayat 1 mengamanatkan bahwa Pemilik Desain Industri yang Dilindungi berhak untuk mencegah pihak ketiga yang tidak mendapat izin dari pemiliknya untuk membuat, menjual atau mengimpor barang yang memuat atau mewujudkan Desain yang merupakan salinan, atau secara substansial salinan, dari Desain yang dilindungi, jika tindakan tersebut. dilakukan untuk tujuan komersial. Dilihat dari pasal tersebut maka pengimitasian suatu barang tidak dapat dibenarkan apalagi jika tujuannya untuk dikomersialkan karena akan merugikan pemegang hak desain industri.

Undang-Undang Tentang Desain Industri harus diperbaharui seiring berkembangnya skema perindustrian produk botol lokal maupun produk lainnya, karena sudah tidak relevan lagi dengan waktu saat ini. Kemajuan di bidang teknologi sudah semakin cepat dan pasti berpengaruh juga terhadap perkembangan terhadap kreatifitas masyarakat umum yang akan berpengaruh terhadap Desain Industri jika tujuannya adalah untuk dikomersialkan dan juga bukan hanya masyarakat Indonesia tetapi masyarakat internasional pun akan merasa terlindungi jika adanya pembaharuan atas Undang-Undang tersebut dan persaingan kreatifitas akan desain industri semakin sehat.

\section{Perlindungan Hukum Bagi Pemegang Hak Desain Industri Botol Berdasarkan Studi Perbandingan Dengan Negara Amerika Serikat}

Di Indonesia masih banyak permasalahan dibidang Kekayaan Intelektual khususnya Desain Industri, oleh karena banyaknya permasalahan tersebut untuk mengatasinya maka penelitian ini melakukan perbandingan dengan negara Amerika Serikat yang lebih matang dengan persoalan Hak Desain Industri. Amerika Serikat yang memiliki berbagai perlindungan untuk pemegang Trade Dress atau di Indonesia disebut dengan Desain Industri.

Bagian 102 (g) Sertifikat 35 Undang-Undang Amerika Serikat menjelaskan bahwa kecuali penemuan itu dibuat oleh orang lain di negara tersebut sebelum pemohon ditemukan dan orang lain itu tidak dicabut atau ditangguhkan, siapa pun berhak untuk mendapatkan paten. Atau membatalkan paten. bahwa. Dalam hal ini, tampaknya aturan first-to-file tidak digunakan, tetapi aturan first-to-invent digunakan. Dalam hal ini, Amerika Serikat memberikan perlindungan kepada pengguna paten sebelumnya. Jika tidak ada pengguna paten sebelumnya, atau pengguna sebelumnya telah membekukan atau membatalkan paten, pemohon memperoleh perlindungan melalui pendaftaran paten.

Bagian 101 Undang-Undang Paten Amerika mensyaratkan kebaruan (novelty) sebagai suatu syarat bisa dipatenkannya sesuatu, demikian pula bahwa suatu penemuan yang bisa dipatenkan merupakan suatu proses, mesin, perekayasaan, atau komposisi sesuatu yang bermanfaat, atau suatu kemajuan yang bermanfaat darinya. Dalam hubungan ini Bagian 102 Undang-Undang Paten Amerika, menetapkan seseorang berhak untuk mendapatkan paten, terkecuali:

a. Penemuan bersangkutan telah dikenal atau digunakan oleh orang lain di negeri ini, atau dipatenkan atau dipaparkan dalam suatu publikasi cetak di negeri ini atau di sebuah negara asing, sebelum penemuan oleh si pemohon paten; atau

b. Penemuan bersangkutan telah dipatenkan atau dipaparkan dalam suatu publikasi cetak di negeri ini atau di sebuah negara asing atau digunakan oleh publik atau dijual di negara ini, lebih dari satu tahun sebelum tanggal permohonan paten di negeri ini; atau

c. Penemuan bersangkutan untuk pertama kalinya dipatenkan atau dibuat untuk dipatenkan, atau menjadi subjek dari sertifikat seorang penemu, oleh si pemohon atau para wakil hukumnya atau orang yang ditunjuknya di sebuah negara asing sebelum tanggal permohonan paten di negara ini atau sertifikat penemu yang diajukan lebih dari 12 bulan sebelum pengajuan permohonan di negeri ini; atau

d. Penemuan dipaparkan dalam sebuah paten yang diberikan atas dasar suatu permohonan untuk paten oleh seseorang lain yang diajukan di negeri ini sebelum penemuan oleh pemohon paten, atau berdasarkan suatu permohonan internasional oleh seseorang lain yang 
telah memenuhi persyaratan untuk memulai level nasional di bawah PCT sebelum penemuannya oleh si pemohon paten.

Syarat lain disebutkan dalam Bagian 103 Undang-Undang, bahwa sebuah paten tidak bisa diperoleh jika perbedaan-perbedaan hukum dalam subject of matter yang diusahakan untuk dipatenkan dan the prior art (penemuan sebelumnya) adalah sedemikian rupa sehingga subject of matter bersangkutan secara keseluruhan, pada saat penemuan dibuat bagi seseorang yang mempunyai keterampilan biasa dalam kecakapan (art) yang dengannya subject of matter bersangkutan berkaitan.

Bagian 102(e) Undang-undang menetapkan bahwa seseorang berhak atas paten kecuali jika penemuan yang bersangkutan telah diajukan dalam suatu paten yang diberikan atas suatu permohonan paten oleh orang lain di mana permohonan lain tersebut diajukan di Amerika Serikat sebelum penemuan yang bersangkutan oleh pemohon paten. Berdasarkan hukum Amerika Serikat, paten dapat digunakan sebagai prior art baik untuk tujuan baru atau untuk tujuan kejelasan, setelah pemberian paten yang relevan, dengan efek prior art berlaku surut hingga tanggal pengajuan efektif paling awal di Amerika Serikat, dan tidak sampai tanggal pengajuan di luar AS. Ini biasanya disebut sebagai "aturan Hilmer".

Dalam hal ini, Amerika Serikat tidak seperti negara-negara Eropa. Perbedaannya lebih kentara, terutama di Belanda dan Jerman. Dalam praktiknya, gunakan prinsip pengemasan dokumen estoppel (File wrapper esttoppel) dan prinsip kesetaraan (doktrin equivalent) untuk menentukan ruang lingkup perlindungan invensi yang dipatenkan. Ada atau tidaknya pelanggaran terhadap suatu invensi yang dipatenkan, kata pertama yang harus diperhatikan adalah klaim, yang artinya penafsiran yang sempit. Namun, pengadilan berpendapat bahwa jika hanya kata-kata yang dipertimbangkan, bentuk akan ditempatkan di atas substansi (dalam arti luas). Tentu saja, itu akan merenggut keuntungan yang awalnya dibuat oleh pemilik penemuan. Hal ini jelas tidak memenuhi tujuan utama dari sistem paten, yaitu mengungkapkan invensi melalui prinsip keterbukaan. Untuk melindungi pemilik invensi yang dipatenkan, prinsip kesetaraan telah dirumuskan.

Menurut doktrin equivalent, jika dua alat mempunyai fungsi yang sama dan pada dasarnya cara kerja yang sama, dan untuk memperoleh hasil yang pada dasarnya sama, kedua alat tersebut dianggap sama, meskipun nama dan bentuk kedua alat tersebut berbeda. Secara umum, prinsip ekuivalensi memang menguntungkan pemilik invensi. Di sisi lain, prinsip ekuivalensi juga dapat digunakan untuk menyerang pemilik invensi. Hal ini terjadi apabila alat yang dipatenkan dimodifikasi sedemikian rupa sehingga cara kerjanya sangat berbeda dengan barang yang dipatenkan, tetapi fungsinya sama dengan alat yang dipatenkan, dan masih tercakup dalam kata-kata klaim. Jika dilakukan oleh inventor lain, dan prinsip ekuivalensi digunakan untuk membatasi klaim dalam sengketa, bukan tidak mungkin prinsip tersebut akan menimbulkan kesulitan bagi penerima paten.

Dalam proses perkembangannya, prinsip ekuivalensi berkaitan dengan prinsip pengemasan dokumen estoppel. Menurut doktrin pengemasan dokumen estoppel, untuk mendapatkan paten, penemu membatasi klaimnya. Jika prinsip pengemasan dokumen estoppel telah digunakan untuk melindungi paten dari pemalsuan, pemegang paten dapat menggunakan prinsip yang setara. Penggunaan doktrin ini saat ini adalah untuk klaim yang ambigu dan sebagai sarana interpretasi. Dalam Alpex Computer Corporation v. Nintendo Company Ltd dan Nintendo America, Inc., Mahkamah Agung AS menyatakan Alpex sebagai pemegang Paten No.4.026, 555 menggugat Nintendo, mengklaim bahwa Nintendo melanggar paten. Dalam hal ini, Nintendo dari Amerika Serikat-salah satu produsen video game terbesar di Jepang-kerugian lebih dari US\$2.000.000.000 (US\$2 miliar) pada awal 1990-an.

Penggugat (Alpex) dan tergugat (Nintendo) adalah produser video game. Status kasus ini bermula di industri video game dan sudah ada sejak awal 1970-an. Saat ini, dua jenis video game dan video game rumahan dikembangkan. Video game dapat ditemukan di tempat-tempat permainan, sedangkan video game rumahan biasanya ditemukan di rumah. Pada tahun 1974, Alpex menemukan sistem yang memungkinkan video game rumahan untuk memainkan 
berbagai permainan, termasuk permainan dengan gambar berputar. Penemuan ini kemudian dipatenkan oleh Alpex pada tahun 1977. Selanjutnya, Attari, Mattel dan Coleco mengkomersialkan penemuan mereka yang dipatenkan dalam sistem ini.

Pada awal 1980-an, Nintendo juga memasuki pasar video game rumahan dengan Nintendo Entertainment System (NES). Setelah NES diresmikan di Consumer Electronics Show pada tahun 1985, Alpex memberi tahu Nintendo bahwa Nintendo telah melanggar patennya. Inilah sebabnya mengapa pada Februari 1986, setelah beberapa penyelesaian di luar pengadilan, Alpex menggugat Nintendo. Di pengadilan tingkat pertama, Alpex menang. Pertimbangan pengadilan adalah tidak ada perbedaan substansial antara alat yang dipatenkan dan alat yang dianggap tiruan dari segi fungsi, metode, dan hasil. Tetapi pengadilan tingkat pertama tidak membuktikan bahwa kedua alat tersebut benar-benar bekerja dengan cara yang sama. Oleh karena itu, interpretasi pengadilan banding terhadap asas kesepadanan tidak hanya bahwa kedua alat tersebut setara dalam hal hasil fungsional, tetapi juga harus dapat membuktikan bahwa keduanya memiliki perbedaan yang tidak substansial dalam metode kerjanya.

Salah satu hal yang penting selain hal diatas dalam menentukan plagiarism terkait hak desain industri produk fesyen dalam hal ini botol adalah unsur kebaruan (novelty) suatu produk. Hal tersebut sesuai dengan amanat Pasal 25 ayat (1) Perjanjian TRIPs disebutkan: Members shall provide for the protection of independently created industrial design that are new or original. Members may provide that design are not new original if they do not significantly differ from known design or combinations of known design features. Members may provide that such protection shall not extend to design dictated essentially by technical or functional considerations (Anggota wajib memberikan perlindungan atas ciptaan desain tidak baru atau tidak asli jika desain tersebut tidak secara signifikan berbeda desain yang dikenal atau kombinasi dari fitur desain yang sudah dikenal. Anggota dapat menentukan bahwa perlindungan tersebut tidak berlaku untuk desain yang pada dasarnya ditentukan oleh pertimbangan teknis atau fungsional). Maka penting untuk mengukur standar Kreatifitas apa yang menjadi acuan untuk dapat mendapatkan perlindungan, menurut regulasi paten Amerika Serikat mengharuskan desain paten menjadi "baru, orisinil dan ornamental".

Di Amerika Serikat, The Fashion Lobby telah mengusulkan setidaknya tiga rancangan undang-undang selama beberapa tahun terakhir. Setiap Rancangan Undang-Undang menggunakan Vessel Hull Design Protection Act (VHDPA) sebagai kerangka kerja untuk memperluas perlindungan ke desain mode. Di bawah versi terbaru dari RUU desain fesyen, VHDP akan diperluas menjadi "pakaian" yang didefinisikan sebagai pakaian dan aksesoris. Definisi ini memungkinkan CFDA untuk berpendapat bahwa penambahan hukum saat ini mudah dan mereka berusaha untuk melindungi anggotanya dari barang palsu karena hukum ini melindungi desain fesyen.

\section{KESIMPULAN}

Perkembangan industri botol Indonesia menimbulkan permasalah pada pemegang hak desain industri botol. Perlindungan kepada pemegang desain botol di Indonesia masih belum baik jika dibandingkan dengan Amerika Serikat, padahal perlindungan hukum adalah salah satu hal paling penting dalam konsep negara hukum. Melindungi hak-hak setiap warganegaranya yang mempunyai desain industri agar tidak diklaim oleh pihak lain. Amerika Serikat dengan sistem hukum common law-nya mempunyai Trade Dress yang melindungi setiap pemegang hak desain industri dan pengadilan mampu menyelesaikan setiap kasus dengan elegan tanpa merugikan pihak yang mempunyai hak desain industri karena Indonesia dalam memberikan perlindungan paten masih berdasarkan prinsip first-to-file, yang berbeda dengan Amerika Serikat berdasarkan prinsip first-to-invent. Sekalipun Amerika Serikat menggunakan prinsip first-to-invent. Amerika Serikat juga menggunakan doktrin "file wrapper estoppel dan equivalent". 


\section{DAFTAR PUSTAKA}

Hanley, Lynsey. "Lockdown has laid bare britain's class divide", https://www.theguardian.com/commentisfree/2020/apr/07/lockdown-britain-victorianclass-divide, diakses pada 23 mei 2021.

Ibrahin, Johny. Teori dan Metodologi Penelitian Hukum Normatif, Surabaya: Bayumedia, Surabaya, 2005.

Indonesia, Undang-Undang No. 31 Tahun 2000 Tentang Desain Industri

Mayana, Ranti Fauza. Perlindungan Desaian Industri di Indonesia Dalam Era Perdagangan Bebas (Desain Industri), Jakarta: Gramedia Widiasarana Indonesia, 2004.

Philips, Jeremy dan Alison Firth. Introduction to Intellectual Property Law, Third Edition, London: Butterworth, 1999.

Saputra, Dhanar Intan Surya, Dkk. "Program pengembangan kewirausahaan industri kreatif di STMIK Amikom Purwokerto', Jurnal Pengabdian dan pemberdayaan masyarakat (2020), Hlm. 53-59.

Setiawan, Hendra. "Penilaian Kebaruan Menurut Hukum Desain Industri Indonesia", http://www.hukumonline.com/berita/baca/hol20446/penilaian-kebaruan-menurut hukumdesainindustri-indonesia, diakses pada tanggal 16 mei 2021.

Soetijanto, Nugroho Amien. Penyusunan Deskripsi Desain Industri, Jakarta, 2005.

Wolfhard, Eric. "International Trade in Intellectual Property: The Emerging GATT Regime", University of Toronto Faculty of Law Revie (1991), hlm. 107.

Yodo, Sutarman. "Perlindungan Hak Paten (Studi Komparatif Lingkup Perlindungan di Berbagai Negara)", Fiat Justisia Jurnal Ilmu Hukum 10 (Oktober - Desember 2016), Hlm. 697-714.

Yuliasih, "Perlindungan Hukum Desain Industri Dalam Pelaksanaan Prinsip Keadilan Menurut Teori Keadilan John Rawls (Studi Kasus Putusan Nomor 35 Pk/Pdt.Sus-HKI-/2014)", Notarius (2 september 2015), Hlm. 152-179. 